UDC: 699.82

\title{
IMPROVING WATERPROOFING PROPERTIES IN THE WALL BASEMENT AREA BY INJECTION METHOD
}

\author{
Filonenko Olena ${ }^{1}$, Leshchenko Maryna ${ }^{2 *}$, Rozdabara Olesia ${ }^{3}$, \\ Duka Oleksandr ${ }^{4}$, Pashchenko Vyacheslav ${ }^{5}$, Filonenko Dmytro ${ }^{6}$
${ }^{1}$ Poltava National Technical Yuri Kondratyuk University https://orcid.org/0000-0001-8571-9089
${ }^{2}$ Poltava National Technical Yuri Kondratyuk University $\underline{\text { https://orcid.org/0000-0003-4618-7053 }}$
${ }^{3}$ Poltava National Technical Yuri Kondratyuk University https://orcid.org/0000-0001-8771-8346 4, 5, 6 Poltava National Technical Yuri Kondratyuk University
*Corresponding author E-mail: mv.leshchenko@gmail.com

\begin{abstract}
The article is focused on the natural experimental research of injection waterproofing impact on basement areas of existing buildings brick walls. Two types of experimental installations for waterproofing material injection have been developed. The second type turned out to be more efficient due to the fact that it could cover larger waterproofing wall area. It can possibly speed up the process of walls waterproofing and major repairs of buildings in general. According to the experimental data, after the injection waterproofing placement, the wall moisture content decreased by half due to the high quality waterproofing material and performed installation work.
\end{abstract}

Keywords: construction, moisture content, injection waterproofing, major repairs, wall basement area.

\section{ПІДВИЩЕННЯ ГІДРОІЗОЛЯЦІЙНИХ ВЛАСТИВОСТЕЙ ПРИФУНДАМЕНТНИХ ЗОН ІН'СКЦІЙНИМ СПОСОБОМ}

\author{
Філоненко О.I. ${ }^{1}$, Лещенко М.В. ${ }^{2 *}$, Роздабара О.M. ${ }^{3}$, \\ Дука О.М. ${ }^{4}$, Пащенко В.В. ${ }^{5}$, Філоненко Д.А. ${ }^{6}$ \\ 1, 2, 3, 4, 5, 6 Полтавський національний технічний університет імені Юрія Кондратюка \\ *Адреса для листування E-mail: mv.leshchenko@gmail.com
}

\begin{abstract}
У статті розглядаються натурні експериментальні дослідження впливу ін'єкційної гідроізоляції на прифундаментні зони цегляних стін існуючих будівель. Експериментальні дослідження з перевірки гідроізоляційних властивостей ін'єкційного матеріалу проводилися в ПолтНТУ. Для даного експерименту було обрано стіну, яка вся контактує з грунтом і не має гідроізоляції. Визначення вологості стіни проводилося декількома способами: 1) контактний поверхневий; 2) локальний; 3) розрахунок масового відношення вологи в матеріалі. До гідроізоляції при контактному поверхневому способі було отримано значення вологості цегляної кладки 8\%, що пояснюється тим, що внутрішня поверхня стіни частково просихає та провітрюється у приміщенні, де знаходиться експериментальна стіна. При локальному способі було отримано значення вологості цегляної кладки 45\%, що пояснюється тим, що відбулося розшарування цегляної суміші і води, тому поверхневий шар, практично мокрий, показав досить високий результат - це поверхнева волога. При подальшому проведенні експерименту було відібрано серію експериментальних зразків для визначення вологості за розрахунком масового відношення вологи в матеріалі. Загальна їх кількість становила 15 штук. Для вибірки визначено середнє значення вологості $\mathrm{W}=18,3 \%$, стандарт $\mathrm{S}=1,39$ й коефіцієнт варіації $\mathrm{V}=0,079$. Після влаштування гідроізоляції було відібрано повторно зразки цегляної стіни та визначено значення вологості. Для вибірки визначено середнє значення вологості $\mathrm{W}=9,1 \%$, стандарт $\mathrm{S}=0,85$ й коефіцієнт варіації $\mathrm{V}=0,093$. В результаті проведення експериментальних досліджень було розроблено два типи експериментальних установок для нагнітання ін'єкційної гідроізоляції. Другий тип більш ефективний, оскільки за його допомогою охоплюється більша горизонтальна гідроізоляційна площа стіни. Згідно з експериментальними даними, після влаштування ін'єкційної гідроізоляції вологість стіни зменшилася у два рази.
\end{abstract}

Ключові слова: будівництво, вологість, ін'єкційна гідроізоляція, капітальний ремонт, прифундаментна зона 


\section{Introduction}

The waterproofing issue is one of the most important in building construction and reconstruction as waterproofing materials ensure building protection from the impact of the corrosive moist environment. Despite the existing and new technologies in this area, the waterproofing issue remains urgent as the right choice of techniques and waterproofing materials enables to increase their working life, decrease operational and maintenance cost, increase the possibility of using the underground parts in buildings and either eliminate or minimize renovation work. Stone buildings and structures suffer from hostile environment influence, in particular from moisture and salinization, which cause local corrosive destruction and quicken the load-bearing capacity loss of the structures unless appropriate measures in their protection are taken.

At present there is a large number of techniques and waterproofing materials which can be classified as follows:

- according to the material used there are bituminous, mineral, polymeric, and metal waterproofing types;

- according to the installation method there is coating, sealing, plaster, casting, penetrative, injection, fill, and mounted waterproofing;

- according to the appearance there is mastic, powder solution, blanket, sheet, film, polymembrane and other types of waterproofing.

Therefore, research focused on a particular type of waterproofing and its impact on the functional capacity of brick walls basement areas is relevant from the theoretical and practical point of view. The paper analyses performance and functional properties of injection waterproofing, implementation of repair techniques of such structures with the prediction of their further service life.

The research was carried out at PoltNTU and its main results were implemented as part of the state-financed applied research work "Comprehensive constructive solutions for energy efficiency of public buildings in the context of Europian integration" (state registration number 0118U001097).

\section{Review of research sources and publications}

Each type of waterproofing has always been investigated as unexpected results have attracted researchers [8]. In the papers $[1,2]$ horizontal waterproofing building in the old housing were studied. Various external preventive treatments of external surfaces for increasing waterproofing of the existing building constructions have been researched in the papers [3-5].

Factors like wetness, temperature and the type of building material have a big impact on the injection waterproofing functionality. The main focus of [6] is on testing penetration abilities of specially created different types of injection gels and their final efficiency in dependence on those factors.

Scientists from China [7] have carried out quite powerful research and investigated the effect of cementitious capillary crystalline waterproofing material on the water impermeability and concrete microstructure.

Definition of unsolved aspects of the problem
In light of previous and many other studies, it could be understood that modern developers encourage the use of injection waterproofing materials for major repairs. At the same time, however, this issue is not studied well from the scientific perspective. There is no specific data on full-scale experimental work on wall basement areas before and after the installation of waterproofing by the injection method.

\section{Problem statement}

The aim of the study is to conduct real experimental research on the impact of injection waterproofing on basement areas of the existing buildings brick walls.

\section{Basic material and results.}

Experimental models description. Experimental research on testing the waterproofing properties of the injection material were conducted in a classroom in the left wing of the central building (on the ground floor) of PoltNTU, which is also a training laboratory, as there is mechanical equipment for conducting power experiments. Since the university was built in the 1930s, at the time when the concept of "waterproofing" did not exist, it affected the state of bearing structures and building envelope at many locations around the central building. The classroom is located in the basement (Fig. 1), which increases the destructive effect of moisture combined with a low-efficiency heating system and insufficient insolation. This place was chosen for the experiment due to the fact that the entire wall is in contact with the soil and, without waterproofing, is completely saturated with moisture.

In parallel with this experiment, injection waterproofing was carried out at two other locations: an espacement between the windows in the PoltNTU central building external wall and the entire perimeter of the outer walls of the public building (Fig. 2).

Experimental elements are external bearing walls of approximately 1.05 meter thickness. The construction of the walls has a three-layer structure: the external and internal bearing layers are made of brick, and between them there is an indent layer, which was afterwards filled with construction debris.

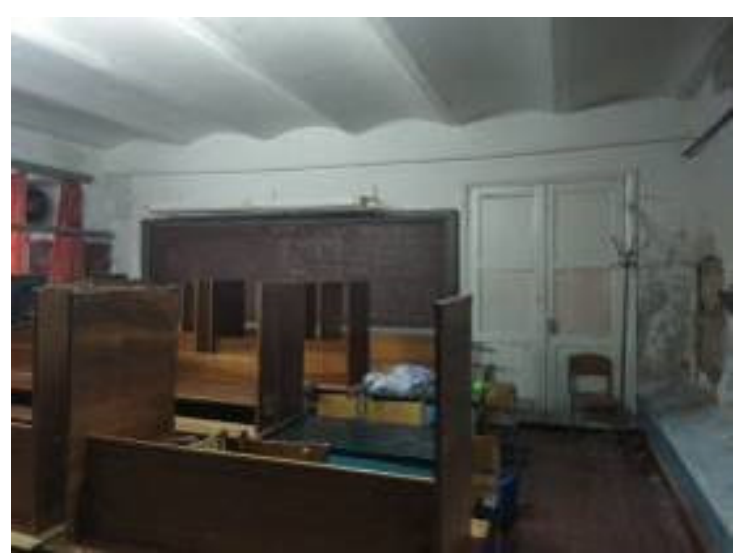

Figure 1 - General view of the experimental room 


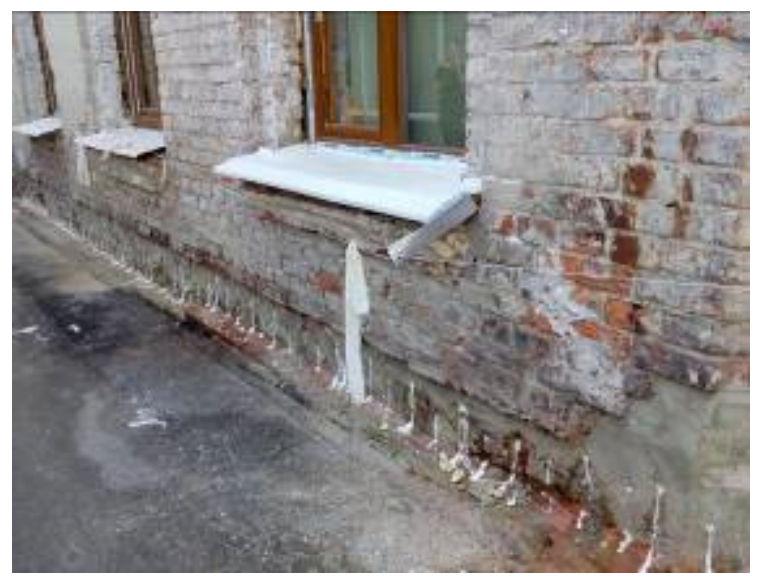

Figure 2 - General view of the experimental external wall

Waterproofing material description. AQUAMAT-F ("АКВAMAT- $\Phi$ ") injection waterproofing was chosen for the experimental study. It is a ready-to-use mixture of water-repellent silicon compounds. When the material is injected into the wall or applied to the surface of the wall for soaking, it penetrates into the smallest pores due to its low viscosity and wettability properties. The capillary structure sealing occurs due to the interaction of the hydrophobic solution with the lime, and formation of water-insoluble chemical compounds crystals that seal pores and stop the capillary penetration of salts on the structure surface. AQUAMAT-F is used mainly to block capillary moisture. It creates a barrier at the wall base, thereby protecting it from the penetration of moisture from the soil.

Experiment conducting methodology. The experiment was carried out in accordance with the manufacturer's technical bulletin. The initial stage was to determine the required location (distance from the angle of the wall was $0.3 \mathrm{~m}$ and from the floor $0.25 \mathrm{~m}$ ). Then, a grid was formed using a measuring tape and a pencil (Fig. 3), which determined the spots for perforation: the distance between the future openings was $0.15 \mathrm{~m}$ in horizontal and vertical directions ( 7 rows with 3 holes in each).

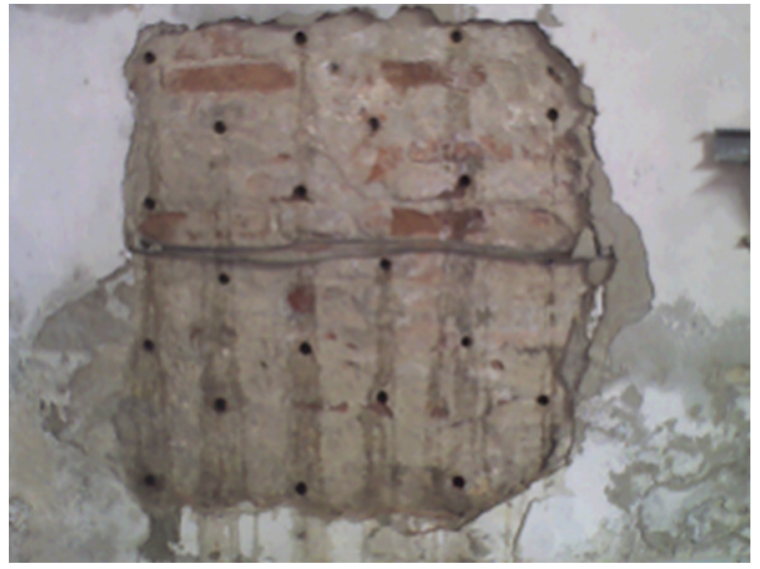

Figure 3 - Perforated wall grid
According to the instructions, perforating was carried out at a small angle not exceeding $30^{\circ}$ using a perforating device. The holes were perforated through the wall thickness, with $5 \mathrm{~cm}$ left imperforated to its outer surface. The diameter of the holes was $18 \mathrm{~mm}$. The final stage of preparatory work was removing the layer of damaged plaster (about $2-3 \mathrm{~cm}$ thick) around the perforated places and to clean the openings from the dust that appeared during the period of work, as the holes must be clean according to the instruction.

The injection system was a construction of plastic hoses $1.5 \mathrm{~m}$ long, fixed on a stand $2.2 \mathrm{~m}$ high for the possibility of free injection in 2 rows at once, even in the highest holes (Fig. 4).

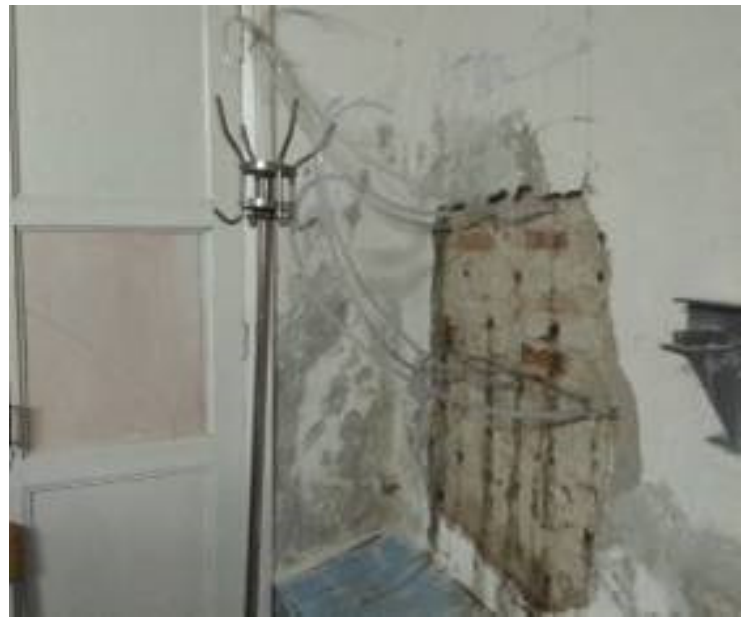

Figure 4 - The first type of experimental installation for injection waterproofing

The hoses were fixed in the holes with the help of gaskets to prevent leakage. Since the waterproofing material has a low viscosity and good wettability, placing the end of the hose above the level of the holes in the wall is enough (without sagging of the hoses) and it is possible to inject the solution even without using compression, which, in fact, was successfully completed.

The penetration of the liquid into each hole was carried out until the liquid began to appear in the pores of the wall.

In the experimental study of the other object, injection waterproofing system shown in Fig. 5 was used. The principle of its work is similar to the previous one. Hoses were inserted into the holes, which were equipped with a mechanism of dropping bottle. Each hole in the wall was insulated with construction foam. This experimental installation was more effective because it could cover a larger horizontal wall area. This can accelerate the process of waterproofing the walls and major repairs of the building in general.

After injecting all the necessary areas of the walls, every hole was filled with a suitable mortar and finished with plaster. 


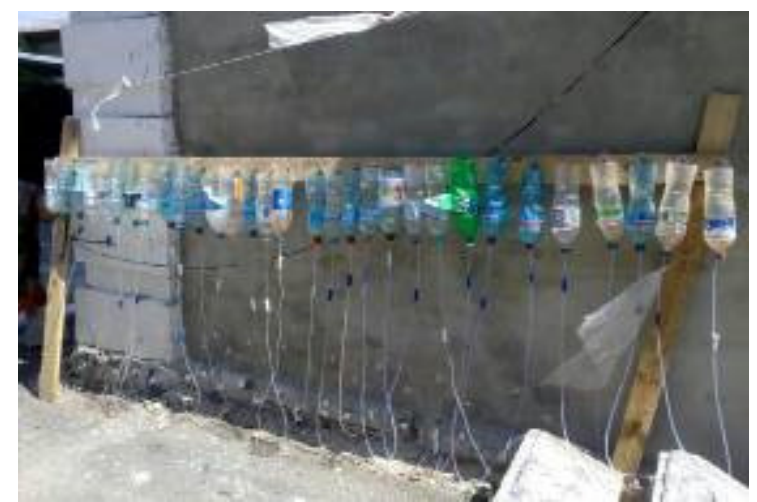

Figure 5 - The second type of experimental installation for injection waterproofing

Experimental research on the moisture content of the wall structure. Some amount of moisture is always present in the building envelope material due to the processes of sorption and condensation of water vapor, which affects the wall thermal qualities.

Determination of moisture content of the experimental wall construction was carried out in several ways:

1) surface contact (with the help of "VIMS 2.21" ("ВИМС 2.21") device);

2) local measurement (with the help of "VIMS 2.21" device);

$3)$ calculation of the mass ratio of moisture in the material (according to the ДСТУ Б В.2.7-170:2008).

Device description. Universal moisture meter "VIMS 2.21" ("ВИМС 2.21") (Fig. 6) is designed for moisture content measurements of solid and fill building materials (light, porous and heavy concrete, sand-lime and ceramic brick, building sand, stone screening dust), wood (timber, chemically untreated wooden parts and products).

The device can be used to measure moisture content of a wide range of solid and fill building materials with their additional calibration and the development and certification of measurement procedure ("MBB").

Application: construction industry, forestry and woodworking industry.

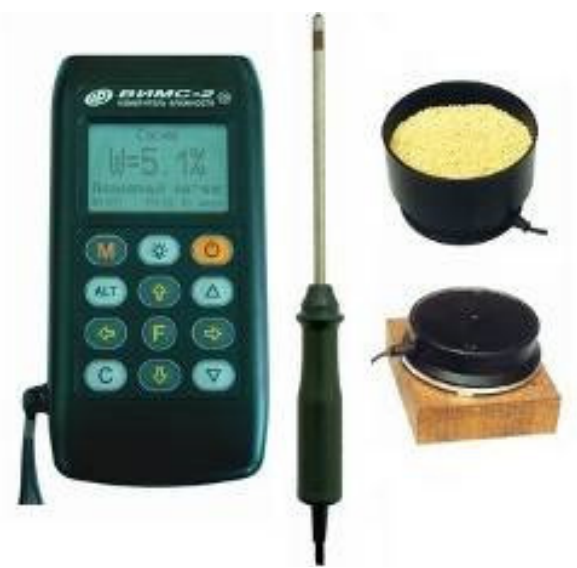

Figure 6 - General view of moisture meter "VIMS 2.21"
The device operating conditions:

- ambient temperature from $5^{\circ} \mathrm{C}$ to $40^{\circ} \mathrm{C}$ above zero;

- relative air humidity from $30 \%$ to $90 \%$;

- single measurement time should not exceed $60 \mathrm{sec}-$ onds.

The device consists of an electronic unit and connected sensors: volumetric-planar capacitive and probe capacitive transducers. Completeness of sensors is determined by the device use.

The volumetric-planar capacitive transducer consists of planar capacitive transducer and a nozzle, which is arranged on the external concentric electrode. According to this parameter the following types are distinguished:

- with a nozzle - volumetric capacitive transducer (volumetric sensor), designed for fill materials moisture content monitoring;

- without a nozzle - planar volumetric transducer (planar sensor), designed for solid materials moisture content monitoring.

The probe capacitive transducer (probe sensor) is used for moisture content monitoring in deep layers of solid, fill and plastic materials. The probe sensor includes a locking screw.

A nozzle for working with fill material can be used in addition to the probe sensor. The nozzle enables to compact the tested fill material and limit its control area.

The device is intended for in-process non-destructive monitoring of sand moisture content, a wide range of building materials, products, structures and buildings in the process of their creation and operation.

An even and smooth surface was prepared prior to measuring the moisture content of bricks in the experimental wall and a tight fitting of the sensors surface to the monitored wall surface was ensured.

For improving the accuracy of the results, moisture content was measured over the series of measurements at different sections of the wall surface, averaging the result by a series of measurements.

The mechanism is based on the dielcometer method of moisture content measurement, namely, the correlation dependence of the material dielectric permeability on the moisture content in it at positive temperatures.

Research results analysis. Moisture content measurement of the brickwork was carried out in two stages: prior to waterproofing and after it.

The first stage: prior to the wall waterproofing. The contact surface method showed that the moisture content of the brickwork was $8 \%$. It is due to the fact that the inner surface of the building envelope (the wall) is partially dried and ventilated in the room where the experimental wall is located.

The local method showed that the value of the brickwork moisture content was $45 \%$. It is due to the fact that there was a segregation of the masonry mixture and water, therefore, the surface layer, practically wet, showed quite a high result - it was the surface moisture.

In the course of the experiment, a series of experimental samples was selected to determine the moisture content by calculating the mass ratio of moisture in the 
material (according to the state standard “ДСТУ Б B.2.7-170:2008”)

$$
W_{m}=\frac{m_{B}-m_{\mathcal{C}}}{m_{B}},
$$

where $m_{b}-$ mass of the material sample prior to drying, $\mathrm{kg}$;

$m_{c}$ - mass of the material sample after drying, $\mathrm{kg}$;

All experimental samples were weighed and then placed in the drying cabinet in a special vessel. Dry materials (Fig. 7) were re-weighed, after which the moisture content of the experimental material was determined.
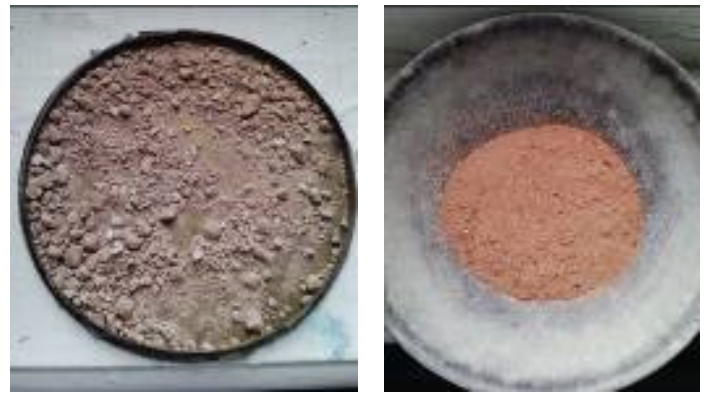

Figure 7 - Dried experimental samples of different walls

In this experimental study moisture content is a varying value; therefore, statistical processing of data was conducted. To obtain reliable estimates of statistical characteristics and distribution laws, the moisture content values of all experimental samples were taken. There were 15 samples in total.

The statistical processing of the samples data of the moisture content value was performed in MS Excel using the embedded statistical functions. For sampling the average humidity value was $\mathrm{W}=18.3 \%$, the standard $\mathrm{S}$ $=1.39$ and the variation coefficient $\mathrm{V}=0.079$, as well as the distribution histogram (Fig. 8) were determined.

After the waterproofing installation, samples of the brick wall were re-selected and, in accordance with the state standard "DSTU Б B.2.7-170:2008", the moisture content was determined. Statistical processing was carried out. For sampling the average moisture value was determined $\mathrm{W}=9.1 \%$, the standard $\mathrm{S}=0.85$ and the coefficient of variation $\mathrm{V}=0.093$, as well as the distribution histogram (Fig. 9) was created.

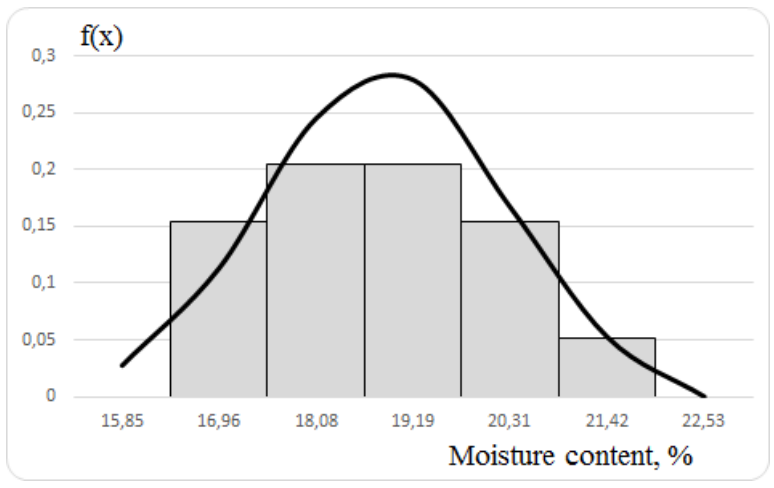

Figure 8 - Distribution histogram of the brick wall moisture distribution prior to waterproofing

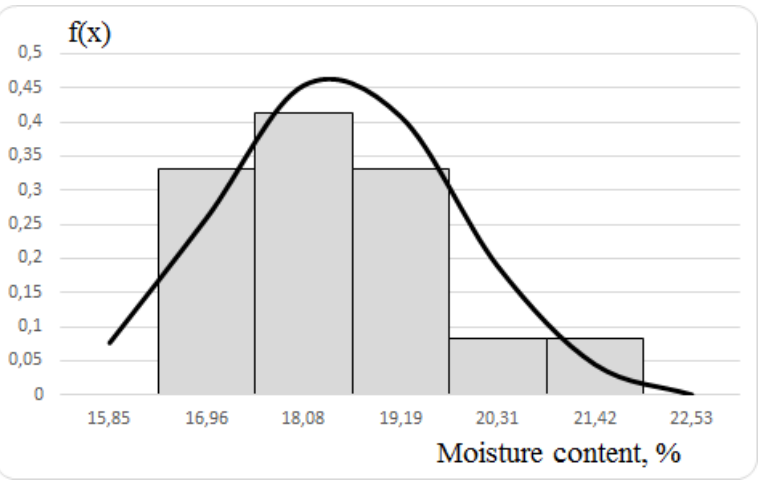

Figure 9 - Distribution histogram of the brick wall moisture distribution after waterproofing

\section{Conclusions}

In the process of experimental research, two types of experimental installations for injection waterproofing have been developed. The second type turned out to be more efficient, due to the fact that it covered wall larger horizontal waterproofing area. It could quicken the process of waterproofing the walls and major repairs of the building. According to experimental data the wall moisture content decreased by half after injection waterproofing. It is due to the high-quality waterproofing material and the implementation of installation arrangement. injection waterproofing has proved itself to be a sufficient high-quality method, but the conditions for waterproofing were near-perfect in the experimental studies, which is not always the case in actual practice.

\section{References}

1. Лучко Й.Й., Назаревич Б.Л., Парнета Б.3. (2005). Технологія влаштування горизонтальної гідроізоляції в цегляних стінах. Ресурсоекономні матеріали, конструкиії, будівлі та споруди, 13, 322-328.

2. Лучко Й.Й., Назаревич Б.Л (2007). Результати експерементальних досліджень заволоженості зразків цегляної стіни. Вісник Одеської державної академії будівництва та архітектури, 26, 201-210.

3. Кравчуновская Т.С., Михайлова И.А., Столяров В.А. (2017). Особенности применения инъекционных строительных материалов ARCAN WATERPROOF при выполнении ремонтно-реконструктивных работ. Строительство, материаловедение, маииностроение: Стародубовские чтения, 90-94.
1. Luchko Y.Y., Nazarevich B.L. \& Parneta B.Z. (2005). The technology of mounting horizontal waterproofing in the brick walls. Resource-Economical Materials, Structures, Buildings and Structures, 13, 322-328.

2. Luchko Y.Y. \& Nazarevich B.L. (2007). Results of experimental studies of the moisture content of brick wall samples. Bulletin of the Odessa State Academy of Civil Engineering and Architecture, 26, 201-210.

3. Kravchunovskaia T.S., Mikhailova I.A. \& Stoliarov V.A. (2017). Features of application of injectable construction materials ARCAN WATERPROOF when performing repair and reconstruction works. Construction, $m a-$ terials science, mechanical engineering: Starodub readings, 90-94. 
4. Sáncheza M., Fariab P., Ferrarac L., Horszczarukd E., Jonkerse H.M., Kwiecieńf A., Mosag J., Peledh A. et. al. (2018). External treatments for the preventive repair of existing constructions: A review. Construction and Building Materials, 193(30), 435-452.

https://doi.org/10.1016/j.conbuildmat.2018.10.173

5. Kapustin F.L., Pomazkin E.P. (2018). Effect of Waterproofing Penetrating Capillary Mixture on Concrete Waterproofness and Cement Stone Microstructure. Power Technology and Engineering, 52(2), 168-171.

https://doi.org/10.1007/s10749-018-0927-z

6. Drochytka R., Černý V., Melichar J. (2017). Examination methods for injection waterproofing screens in various building materials. Materiali in Tehnologije, 51(3), 529532.

https://doi.org/10.17222/mit.2015.192

7. Zhang Yi Teng, Zuo Lian, Yang Jin Chao, Zhao Wei Xia, Zeng Xiang Xiong. (2019). Influence of Cementitious Capillary Crystalline Waterproofing Material on the Water Impermeability and Microstructure of Concrete. Materials Science Forum, 953, 209-214.

https://doi.org/10.4028/www.scientific.net/MSF.953.209

8. Filonenko O. (2017). Definition of the parameters of thermal insulation in the zone of building foundation according to the ground freezing depth. Energy Efficiency, 11(3), 603-626.

https://doi.org/10.1007/s12053-017-9600-x
4. Sáncheza M., Fariab P., Ferrarac L., Horszczarukd E., Jonkerse H.M., Kwiecieńf A., Mosag J., Peledh A. et. al. (2018). External treatments for the preventive repair of existing constructions: A review. Construction and Building Materials, 193(30), 435-452.

https://doi.org/10.1016/j.conbuildmat.2018.10.173

5. Kapustin F.L. \& Pomazkin E.P. (2018). Effect of Waterproofing Penetrating Capillary Mixture on Concrete Waterproofness and Cement Stone Microstructure. Power Technology and Engineering, 52(2), 168-171.

https://doi.org/10.1007/s10749-018-0927-z

6. Drochytka R., Černý V., Melichar J. (2017). Examination methods for injection waterproofing screens in various building materials. Materiali in Tehnologije, 51(3), 529532.

https://doi.org/10.17222/mit.2015.192

7. Zhang Yi Teng, Zuo Lian, Yang Jin Chao, Zhao Wei Xia, Zeng Xiang Xiong. (2019). Influence of Cementitious Capillary Crystalline Waterproofing Material on the Water Impermeability and Microstructure of Concrete. Materials Science Forum, 953, 209-214.

https://doi.org/10.4028/www.scientific.net/MSF.953.209

8. Filonenko O. (2017). Definition of the parameters of thermal insulation in the zone of building foundation according to the ground freezing depth. Energy Efficiency, 11(3), 603-626.

https://doi.org/10.1007/s12053-017-9600-x 